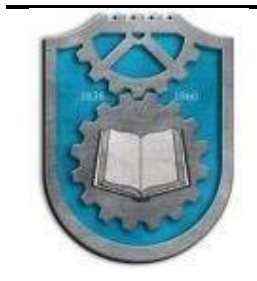

MOBILITY \& VEHICLE MECHANICS

DOI: $10.24874 / \mathrm{mvm} .2021 .47 .03 .02$

UDC: 66.018

\title{
OPTIMIZATION OF ZINC-BASED HYBRID NANOCOMPOSITES USING TAGUCHI GREY RELATION ANALYSIS
}

\author{
Onur Güler ${ }^{1}$ *, Sandra Gajević ${ }^{2}$, Slavica Miladinović ${ }^{3}$, Hamdullah Çuvalcl ${ }^{4}$, Blaža \\ Stojanovic ${ }^{5}$
}

Received in July 2020

Revised in August 2020

Accepted in February 2021

RESEARCH ARTICLE

\begin{abstract}
Hybrid nanocomposites have wide application in many industries. Nanocomposites with base alloy ZA27 reinforced with $\mathrm{Al}_{2} \mathrm{O}_{3}$ and $\mathrm{Gr}$ are commonly used for bearing applications. Taguchi based Grey relational analysis (GRA) was applied for the multi response optimization of parameters of nanocomposite for improving the tribological characteristics. In this investigation considered parameters are load $(10,15,20,25 \mathrm{~N})$, reinforcement content of $\mathrm{Gr}$ and $\mathrm{Al}_{2} \mathrm{O}_{3}(1,2,3,4$ vol.\%), while time and speed are constant as $30 \mathrm{~min}$ and $100 \mathrm{rpm}$, respectively. ANOVA analysis was used to determine influence parameters on wear loss and coefficient of friction $(\mathrm{CoF})$ of nanocomposite. It was observed that the most influential parameter on tribological characteristics of nanocomposites was reinforcement content of $\mathrm{Al}_{2} \mathrm{O}_{3}$. Combination of parameters for optimal tribological characteristics is $\mathrm{A} 1 \mathrm{~B} 1 \mathrm{C} 4$ i.e. load of $10 \mathrm{~N}$, reinforcement content of 1 vol.\% $\mathrm{Gr}$ and reinforcement content of 4 vol. $\% \quad \mathrm{Al}_{2} \mathrm{O}_{3}$. Obtained nanocomposite has shown good tribological properties which lead to less wear loss and therefore expectedly longer life of the bearing in various segments of the automotive industry.
\end{abstract}

KEY WORDS: nanocomposite, optimization, wear loss, coefficient of friction, Taguchi Grey relational analysis

(C) 2021 Published by University of Kragujevac, Faculty of Engineering

\footnotetext{
${ }^{I}$ Onur Güler, Research assistant, Karadeniz Technical University, Department of Metallurgical and Materials Engineering, 61080,Trabzon,Turkey, onurguler@ktu.edu.tr (*Corresponding author) ${ }^{2}$ Sandra Gajević, Teaching assistant, Faculty of Engineering University of Kragujevac, Department of Mechanical Constructions and Mechanization, Sestre Janjic 6, 34000 Kragujevac, Serbia, sandrav@kg.ac.rs

${ }_{3}^{3}$ Slavica Miladinović, Research assistant, Faculty of Engineering University of Kragujevac, Department of Mechanical Constructions and Mechanization, Sestre Janjic 6, 34000 Kragujevac, Serbia, slavicam@kg.ac.rs

${ }^{4}$ Hamdullah Çuvalcl, PhD prof., Karadeniz Technical University, Department of Metallurgical and Materials Engineering, 61080, Trabzon, Turkey, hcuvalci@ktu.edu.tr

${ }^{5}$ Blaža Stojanović, Associate prof., Faculty of Engineering University of Kragujevac, Department of Mechanical Constructions and Mechanization, Sestre Janjic 6, 34000 Kragujevac, Serbia, $\underline{\text { blaza@kg.ac.rs }}$
} 


\section{OPTIMIZACIJA HIBRIDNIH NANOKOMPOZITA BAZIRANIH NA CINKU KORIŠĆENJEM TAGUCHI SIVE ANALIZE}

REZIME: Hibridni nanokompoziti imaju široku primenu u mnogim industrijama. Nanokompoziti sa baznom legurom ZA27 ojačani $\mathrm{Al}_{2} \mathrm{O}_{3}$ i Gr uobičajeno se koriste kod ležajeva. Grejeva relaciona analiza (GRA) zasnovana na Taguči metodi primenjena je za optimizaciju parametara nanokompozita kako bi se poboljšale tribološke karakteristike. U ovom istraživanju razmatrani su parametri: opterećenje $(10,15,20,25 \mathrm{~N})$, sadržaj ojačanja Gr i $\mathrm{Al} 2 \mathrm{O} 3$ (1, 2, 3, 4 vol.\%), dok su vreme $30 \mathrm{~min}$ i brzina $100 \mathrm{o} / \mathrm{min}$ bili konstantni. Analizom ANOVA utvrđeni su parametri koji deluju na smanjenje habanja i koeficijenta trenja (CoF) nanokompozita. Uočeno je da je najuticajniji parametar na tribološke karakteristike nanokompozita sadržaj ojačanja $\mathrm{Al}_{2} \mathrm{O}_{3}$. Kombinacija parametara za optimalne tribološke karakteristike je: A1B1C4, odnosno opterećenje od $10 \mathrm{~N}$, sadržaj ojačanja 1 vol.\% Gr i sadržaj ojačanja 4 vol.\% $\mathrm{Al}_{2} \mathrm{O}_{3}$. Dobijeni nanokompozit pokazao je dobra tribološka svojstva koja dovode do manjeg habanja i stoga očekivano duži vek trajanja ležaja u različitim segmentima automobilske industrije.

KLJUČNE REČI: nanokompozit, optimizacija, smanjenje habanja, koeficijent trenja, Taguči Grej relaciona analiza 


\title{
OPTIMIZATION OF ZINC-BASED HYBRID NANOCOMPOSITES USING TAGUCHI GREY RELATION ANALYSIS
}

\author{
Onur Güler, Sandra Gajević, Slavica Miladinović, Hamdullah Çuvalcı, Blaža Stojanović
}

\section{INTRODUCTION}

Successful and wide use of composite material has led to a development of a new field of research in engineering-nanocomposites. Nanocomposite is a material which consist of base material and reinforcement (particles, short and long fibers, tubes) whose one dimension is less than $100 \mathrm{~nm}$. There are three types of nanocomposites, depending of the base material, and they are: Metal Matrix Nanocomposites (MMNC's), Polymer Matrix Nanocomposites (PMNC's) and Ceramic Matrix Nanocomposites (CMNC's). All of these nanocomposites have found their application in various industries, according to their mechanical and tribological characteristics. In automotive industry nanocomposites, especially with particle reinforcement, are applied for vehicles' body parts, chassis and tires, automotive interiors, electrical and electronics, and other [1]. Mostly used materials for base of composites are aluminium, magnesium, copper, zinc and titanium. Among various alloys used for MMC, zinc-based alloys are gaining wide spread popularity as a cost effective substitute. Zincbased alloy ZA-27 has superior weight-to-strength ratio, as well as good corrosion and wear resistance. Because of their good tribological and mechanical properties these alloys are used for sliding bearings [2]. A lot of optimization methods are applied for increasing productivity, development and manufacturing of nanocomposites. In automotive industry there has been a great interest for use of optimization in aim of reduction of vehicle weight, costs of production and fuel consumption. Widely used optimization method is Taguchi analysis which is used for determination of the effects of all process parameters using a small number of experiments, but it is only applied for optimization of single response. In case of multi response optimization Taguchi is paired with Grey relation analysis (GRA). Investigation of tribological and mechanical characteristics of ZA27 composites on micro/nano scale was done by Babic et al. Nanocomposites with particle contents of 1,3 , and $5 \mathrm{vol} . \% \mathrm{SiC}$ (mean size of $50 \mathrm{~nm}$ ) were used as reinforcement and manufactured with the compocasting process. They concluded that wear resistance of nanocomposite improves with the increase of content of $\mathrm{SiC}$ nanoparticles in relation to base alloy. As for mechanical characteristics they concluded that with reduction of porosity micro/nano hardness increases. The highest porosity was for 1 vol.\% $\mathrm{SiC}$ [3]. Influence of reinforcement on tribological characteristics of hybrid nanocomposite was investigated by Güler et al. They established that the lowest wear was for reinforcement content of 4 vol.\% Gr and 4 vol.\% $\mathrm{A} 12 \mathrm{O} 3$, and highest was for the base alloy. It was found that wear mechanism of nanocomposite was adhesion [4]. Pul et al. observed influence of nano reinforcement $(0.5$, 1.0, 2.0 and 4.0 wt.\% Gr) and different sintering temperatures on tribological and mechanical characteristics of nanocomposite. By analysis of the results they concluded that with increase of content of nano reinforcement in ZA27 the porosity increased and mechanical strength decreased [5]. Taguchi method was applied by Kumar et al. for optimization of dry sliding wear performance of hybrid nanocomposite. Nanocomposites' consisted of ZA base alloy with ceramic reinforcement $(1.5 \mathrm{wt} . \% \mathrm{SiC})$ and soft graphite $(0.5$ wt. $\% \mathrm{Gr}$ ) produced with ultrasonic assisted stir casting. With ANOVA analysis it was found that most influential parameter is distance and then with the use of $\mathrm{S} / \mathrm{N}$ ratio optimal combination for minimum wear volume loss was established (sliding speed $1.5 \mathrm{~m} / \mathrm{s}$, load 40 $\mathrm{N}$ and sliding distance $500 \mathrm{~m}$ ). Additionaly they found that hybrid composite showed better tribological properties in compare to base alloy [6]. Another use of Taguchi method for wear 
optimization of ZA27/SiC nanocomposites was observed in research of Almomani et al. [7]. They applied Taguchi L16 orthogonal array with variation of following parameters SiC content (2, 3, and $4 \mathrm{wt} . \%)$, sliding speed (150 and $200 \mathrm{rpm})$ and load (40 and $75 \mathrm{~N})$. Unlike conclusions made by Babic et al. [3] authors in this research found that with increase of SiC weight fraction, porosity content of MMNC's increased. By applying ANOVA analysis they observed that statistically significant parameters on wear rate are reinforcement contents and normal load. Based on SEM analysis wear mechanism of nanocomposite was abrasive wear. Stir casting fabricated nanocomposites with ZA alloy base and $\mathrm{Al}_{2} \mathrm{O}_{3}$ nanoparticles $(1,2$ and 3 wt.\%) were investigated by Shivakumar et al. [8]. It was noted that with increase of $\mathrm{Al}_{2} \mathrm{O}_{3}$ content microhardness increases and density of the nanocomposites decreases. Tribological testing and analysis of results was based on Taguchi orthogonal array L16. Optimal combination of parameters for minimum wear volume loss was as following: content of 3 wt. $\% \mathrm{Al}_{2} \mathrm{O}_{3}$, sliding speed of $1 \mathrm{~m} / \mathrm{s}$, load of $30 \mathrm{~N}$ and sliding distance of $750 \mathrm{~m}$. ANOVA analysis determined that the most significant parameter for minimum wear volume loss was sliding distance. Improvement of mechanical characteristics of ZA27 based nanocomposites compared to base alloy was presented by Bobić et al. [9]. Nanocomposites with nanoparticle reinforcement of $\mathrm{Al}_{2} \mathrm{O}_{3}(20-30$ and $100 \mathrm{~nm})$ and $\mathrm{SiC}(50 \mathrm{~nm})$ were fabricated with mechanical milling and compocasting. Compared to base alloy improvements are shown in percents through hardness and yield strength [9]. Improvements of hardness of zinc-based nanocomposites are proven by Karimzadeh et al. in [10]. In their research they stated that microhardness of nanocomposites (350 HV) improved and was 10-15 times higher than that of the zinc based (20-30 HV). Based on literature review it can be observed that there is a small number of research and published results for tribological behaviour of ZA 27 based nanocomposites. Generally by observing the research of other composites' optimization methods were widely applied, as well as their combinations such as: ANN-Taguchi, RSMTaguchi Grey and GA-ANN-PSO. A large variety of research was done with the use of statistical methods in the aim of establishing the relationship between optimal mixing proportion of material, tribological and mechanical properties, surface roughness, parameters of material processing, welding parameters, and others. Optimization of relationship between wear loss, coefficient of friction, load and reinforcement $\mathrm{Gr}$ and $\mathrm{Al}_{2} \mathrm{O}_{3}$ by Taguchi Grey method has not yet been investigated. This paper investigates tribological properties of ZA-27 nanocomposites using multi response optimization method for reduction of experiments' time and cost. Taguchi Grey performs multi response optimization by converting it to a single relational grade. Author Güler et al. in their research, concluded which composition of nanocomposites has the highest wear resistance but they didn't take into account both responses at the same time (CoF and wear loss). Purpose of this paper is to examine the parameters with the most significant effect on wear loss and CoF. By using Taguchi Grey analysis importance order of load, and reinforcement content of $\mathrm{Gr}$ and was determined and ANOVA analysis gave statistically significant parameters.

\section{EXPERIMENTAL SETUP}

\subsection{Material}

ZA-27 alloy has been taken as base material for preparation of nanocomposites. The chemical composition of the ZA-27 base alloy consists of $\mathrm{Al}$ (25-28 wt.\%), Cu (2.0-2.5 wt.\%), $\mathrm{Mg}$ (0.01-0.02 wt.\%) and $\mathrm{Zn}$ (balance). nanoparticles of $\mathrm{Al}_{2} \mathrm{O}_{3}$ and $\mathrm{Gr}$ have been selected as reinforcement material with average particle size of $50 \mathrm{~nm}$ and $100 \mathrm{~nm}$, respectively. Mechanical milling process was used in the production of nanocomposite powders including 1-4 vol.\% $\mathrm{Al}_{2} \mathrm{O}_{3}$ and $\mathrm{Gr}$ reinforcement particles and $\mathrm{ZA} 27$ base powders.

Mobility \& Vehicle Mechanics, Vol. 47, No. 3, (2021), pp 9-22 
Mechanical milling operations were carried out in a planetary milling machine (Retsch PM 100) containing chamber and balls made of tungsten carbide. The rotation speed of $300 \mathrm{rpm}$, the ball: powder ratio of 5:1 and the milling time of $8 \mathrm{~h}$ were selected as milling parameters [11]. In order to prevent the sticking of ZA27 base powders having a ductile structure into the milling chamber walls during milling, $3 \%$ by weight of methanol was used as the process control agent (PCA). Firstly, nanocomposite powders produced by mechanical milling were cold pressed under a pressure of $175 \mathrm{MPa}$ in a mold made of hot work steel. Later, nanocomposite samples were fabricated by hot pressing process with sintering of the cold-pressed samples in the mold for $4 \mathrm{~h}$ at $432{ }^{\circ} \mathrm{C}$ and pressing them under $350 \mathrm{MPa}$ to obtain the final nanocomposite samples. Tribometer with contact geometry block-on-ring is used to test the dry sliding wear behavior of $\mathrm{ZA}-27 / \mathrm{Al}_{2} \mathrm{O}_{3} / \mathrm{Gr}$ nanocomposites in which the observed response was the coefficient of friction and wear loss. The details about other production and wear tests were comprehensively indicated in the previous study [4].

\subsection{Design of experiments}

A lot of statistical methods are used nowadays to observe the effect of controllable parameters on response, one of them is Taguchi method. This method uses orthogonal arrays in order to reduce experimental errors, number of experiments, time and cost, enhance the efficiency, optimize the process parameters and reproducibility of experiments. In this paper, three four-level factors, shown in Table 1, were considered in order to obtain the optimum combination for the nanocomposite with the lowest coefficient of friction and wear loss.

Table 1 Name and level of parameters

\begin{tabular}{|l|l|l|l|l|l|}
\hline Parameters & Units & Level I & Level II & Level III & Level IV \\
\hline A: Load & $\mathrm{N}$ & 10 & 15 & 20 & 25 \\
\hline B: Content of Gr & vol.\% & 1 & 2 & 3 & 4 \\
\hline C: Content of Al2O3 & vol.\% & 1 & 2 & 3 & 4 \\
\hline
\end{tabular}

Taguchi mixed L16 orthogonal array (Table 2) was obtained using MINITAB19 statistical software.

Table 2 Experimental results and L16 orthogonal array

\begin{tabular}{|l|l|l|l|l|l|}
\hline No.exp. & A & B & C & CoF & Wear loss (mg) \\
\hline 1 & 10 & 1 & 1 & 0.343254 & 9.8 \\
\hline 2 & 10 & 2 & 2 & 0.267246 & 9.0 \\
\hline 3 & 10 & 3 & 3 & 0.335479 & 10.0 \\
\hline 4 & 10 & 4 & 4 & 0.235487 & 6.2 \\
\hline 5 & 15 & 1 & 2 & 0.325102 & 6.5 \\
\hline
\end{tabular}




\begin{tabular}{|l|l|l|l|l|l|}
\hline 6 & 15 & 2 & 1 & 0.294563 & 16.6 \\
\hline 7 & 15 & 3 & 4 & 0.299985 & 9.2 \\
\hline 8 & 15 & 4 & 3 & 0.267863 & 12.1 \\
\hline 9 & 20 & 1 & 3 & 0.262101 & 8.9 \\
\hline 10 & 20 & 2 & 4 & 0.236892 & 10.4 \\
\hline 11 & 20 & 3 & 1 & 0.387983 & 21.4 \\
\hline 12 & 20 & 4 & 2 & 0.364786 & 26.3 \\
\hline 13 & 25 & 1 & 4 & 0.235075 & 6.3 \\
\hline 14 & 25 & 2 & 3 & 0.243154 & 8.8 \\
\hline 15 & 25 & 3 & 2 & 0.379857 & 21.1 \\
\hline 16 & 25 & 4 & 1 & 0.385413 & 30.2 \\
\hline
\end{tabular}

\subsection{ANOVA and Grey relation analysis (GRA)}

Within Taguchi method final step is identification of influence of each parameter on the response parameters using Analysis of Variance (ANOVA). ANOVA was performed with the assumption of $95 \%$ confidence level to get the desired response. Small variation of factors with high influence will result in high impact on the response. Also, influence of factors can be determined with $\mathrm{P}$ value, if $\mathrm{P}$ is less than 0.05 then factor has significance and if $\mathrm{P}$ value is greater, then factor is not significant $[7,8,12]$. If there is more than one response then multi response optimization is needed, one of methods used for this kind of optimization is Grey relation analysis. GRA converts multiple responses into a single response. At the end of GRA Grey relation grade is obtained, and combination of factors that has a highest value of grey relational grade is the closest to the optimal parameter setting.

First step of GRA is normalization of experiment results in range of 0-1. Depending if the minimization, maximization or nominal value of responses is needed there are three types of equations for normalization. In this study minimization of responses is needed so the normalization equation smaller-the-better is used, with following form:

$$
x_{i}^{*}(k)=\frac{\max x_{i}(k)-x_{i}(k)}{\max x_{i}(k)-\min x_{i}(k)}
$$

where $\max x_{i}(k)$ is maximum value of experiment response, $\min x_{i}(k)$ is minimum value of experiment response, $x_{i}(k)$ is original reference sequence, $i$ is number of experiments (in this case $i=1 \ldots 16$ ) and $k$ is number of responses ( $k=1$ for $\mathrm{CoF}, k=2$ for wear loss). 
After normalization next step of GRA is calculation of Deviation sequence (equation 2) and finding Grey relational coefficients (GRC) for every experiment response with the use of equation 3.

$$
\Delta_{0 i}(k)=\left\|x_{0}^{*}(k)-x_{i}^{*}(k)\right\|
$$

$\Delta_{0 i}(k)$ is deviation sequence for reference sequence $x_{0}^{*}(k)$ and comparability sequence $x_{i}^{*}(k)$

$$
\xi_{i}(k)=\frac{\Delta_{\min }+\varphi \Delta_{\max }}{\Delta_{0 i}(k)+\varphi \Delta_{\max }}
$$

Where, as already said, $\Delta_{0 i}(k)$ is deviation sequence for reference sequence $x_{0}^{*}(k)$ and comparability sequence $x_{i}^{*}(k), \varphi$ is distinguishing coefficient $(0<\varphi<1)$ and is taken as $0.5, \Delta_{\min }$ and $\Delta_{\max }$ are the smallest value and the largest value of $\Delta_{0 i}(k)$ respectively. After obtaining GRC for every experiment response Grey relational grade (GRG) can be calculated as:

$$
\gamma_{i}=\frac{1}{n} \sum_{k=1}^{n} w_{k} \xi_{i}(k)
$$

where $\gamma_{i}$ is the overall grey relational grade, $n$ is the number of test $w_{k}$, represents the weight factor for the $i$-th performance characteristic [13]. Weight factors are different for each parameter, because in real engineering importance of various factors is different, so obtaining them is very important in GRA. Most of researchers take that the weight factors are equal, but in this research will be taken in account real weight factor of parameters.

\section{ANALYSIS AND DISCUSSION OF THE EXPERIMENTAL RESULTS}

Based on the design of experiments tribological testing was conducted and experimental results for $\mathrm{CoF}$ and wear loss were obtained. It is important to mention that the parameters of experiment time and speed were constant and selected as $30 \mathrm{~min}$ and $100 \mathrm{rpm}$ respectively. In this section results of Taguchi Grey analysis of obtained experimental results are presented. Within Taguchi analysis calculation of $\mathrm{S} / \mathrm{N}$ ratios of the experimental results was done and is given in Table 2. $\mathrm{S} / \mathrm{N}$ ratio for all experimental responses for $\mathrm{CoF}$ and wear loss is calculated and given in Table 2, while Table 3 and 4 show effect of each parameter on responses and order of their importance (Rank).

\begin{tabular}{|l|l|l|l|}
\hline \multirow{2}{*}{ Table 3 Response table for S/N ratios of CoF } \\
\hline \multirow{2}{*}{ Level } & \multicolumn{2}{|l|}{ Parametres } \\
\cline { 2 - 4 } & A & B & C \\
\hline 1 & $\mathbf{1 0 . 6 9 9}$ & 10.813 & 9.102 \\
\hline 2 & 10.569 & $\mathbf{1 1 . 7 1 7}$ & 9.597 \\
\hline
\end{tabular}




\begin{tabular}{|l|l|l|l|}
\hline 3 & 10.281 & 9.144 & 11.210 \\
\hline 4 & 10.387 & 10.261 & $\mathbf{1 2 . 0 2 6}$ \\
\hline Delta & 0.419 & 2.573 & 2.924 \\
\hline Rank & 3 & 2 & 1 \\
\hline Edelta & 5.916 & & \\
\hline Weight & 0.24 & & \\
\hline
\end{tabular}

Optimal combination of parameters for $\mathrm{CoF}$ is $\mathrm{A} 1 \mathrm{~B} 2 \mathrm{C} 4$ i.e. $10 \mathrm{~N}, 2$ vol.\% $\mathrm{Gr}$ and 4 vol.\% $\mathrm{Al}_{2} \mathrm{O}_{3}$.

Table 4 Response table for $S / N$ ratios of wear loss

\begin{tabular}{|l|l|l|l|}
\hline \multicolumn{4}{|l|}{ Parametres } \\
\hline Level & A & B & C \\
\hline 1 & $\mathbf{- 1 8 . 6 9}$ & $\mathbf{- 1 7 . 7 6}$ & -25.11 \\
\hline 2 & -20.40 & -20.68 & -22.56 \\
\hline 3 & -23.58 & -23.09 & -19.88 \\
\hline 4 & -22.74 & -23.88 & $\mathbf{- 1 7 . 8 6}$ \\
\hline Delta & 4.89 & 6.11 & 7.25 \\
\hline Rank & 3 & 2 & 1 \\
\hline Delta & 18.25 & & \\
\hline Weight & 0.76 & & \\
\hline
\end{tabular}

Based on Table 4 minimal wear loss is achieved with A1B1C4 i.e. $10 \mathrm{~N}, 1$ vol.\% Gr and 4 vol. $\% \mathrm{Al}_{2} \mathrm{O}_{3}$ which is the optimal combination of parameters for wear loss.

\subsection{Analysis of variance (ANOVA) and Grey relation analysis}

GRA was applied for investigation of wear behaviour of ZA27 nanocomposites. First normalization of responses was done, then deviation sequence and GRC were calculated with the use of equations 1-3. Normalized results and GRC are given in Table 5.

Next step, based on S/N analysis (Tables 3 and 4) and equation 5, weights of each response were obtained ( $24 \%$ and $76 \%$ for $\mathrm{CoF}$ and wear loss) and GRG was calculated with equation 6. 


$$
w_{i}=\frac{\sum_{j=1}^{p} \text { Delta }_{i, j}}{\sum_{i=1}^{m} \sum_{j=1}^{p} \text { Delta }_{i, j}}
$$

where $m$ is the number of response, $p$ is the number of parameters and Delta presents the $\mathrm{S} / \mathrm{N}$ ratio range from Table 3 and 4.

$$
G R G=0.24 G R C_{C O F}+0.76 G R C_{\text {WEARLOSS }}
$$

GRG were calculated to determine the effects of parameters on the experiment results and ranked for each series (Table 5).

\begin{tabular}{|c|c|c|c|c|c|c|c|c|}
\hline $\begin{array}{l}\text { No. } \\
\text { exp. }\end{array}$ & $\begin{array}{l}\mathrm{S} / \mathrm{N} \\
\text { ratio for } \\
\mathrm{CoF}\end{array}$ & $\begin{array}{l}\mathrm{S} / \mathrm{N} \\
\text { ratio for } \\
\text { wear } \\
\text { loss }\end{array}$ & $\begin{array}{l}\text { NORM. } \\
\text { CoF }\end{array}$ & $\begin{array}{l}\text { NORM. } \\
\text { Wear } \\
\text { loss }\end{array}$ & $\begin{array}{l}\text { Grey } \\
\text { coefficient } \\
\mathrm{CoF}\end{array}$ & $\begin{array}{l}\text { Grey } \\
\text { coefficient } \\
\text { Wear loss }\end{array}$ & GRG & RANK \\
\hline 1 & 9.2877 & $\begin{array}{l}- \\
19.8245\end{array}$ & 0.2925 & 0.8500 & 0.4141 & 0.7692 & 0.6840 & 9 \\
\hline 2 & 11.4618 & $\begin{array}{l}- \\
19.0849\end{array}$ & 0.7896 & 0.8833 & 0.7038 & 0.8108 & 0.7851 & 7 \\
\hline 3 & 9.4867 & $\begin{array}{l}- \\
20.0000\end{array}$ & 0.3434 & 0.8417 & 0.4323 & 0.7595 & 0.6810 & 10 \\
\hline 4 & 12.5607 & $\begin{array}{l}- \\
15.8478\end{array}$ & 0.9973 & 1.0000 & 0.9946 & 1.0000 & 0.9987 & 1 \\
\hline 5 & 9.7596 & $\begin{array}{l}- \\
16.2583\end{array}$ & 0.4112 & 0.9875 & 0.4592 & 0.9756 & 0.8517 & 3 \\
\hline 6 & 10.6164 & $\begin{array}{l}- \\
24.4022\end{array}$ & 0.6110 & 0.5667 & 0.5624 & 0.5357 & 0.5421 & 12 \\
\hline 7 & 10.4580 & $\begin{array}{l}- \\
19.2758\end{array}$ & 0.5755 & 0.8750 & 0.5408 & 0.8000 & 0.7378 & 8 \\
\hline 8 & 11.4417 & $-\overline{21.6557}$ & 0.7856 & 0.7542 & 0.6999 & 0.6704 & 0.6775 & 11 \\
\hline 9 & 11.6306 & $\overline{18.9878}$ & 0.8233 & 0.8875 & 0.7388 & 0.8163 & 0.7977 & 5 \\
\hline 10 & 12.5090 & $\overline{2}-3407$ & 0.9881 & 0.8250 & 0.9768 & 0.7407 & 0.7974 & 6 \\
\hline 11 & 8.2237 & $\overline{26.6083}$ & 0.0000 & 0.3667 & 0.3333 & 0.4412 & 0.4153 & 14 \\
\hline 12 & 8.7592 & - & 0.1517 & 0.1625 & 0.3708 & 0.3738 & 0.3731 & 15 \\
\hline
\end{tabular}

Table 5 Results of Grey relational analysis 


\begin{tabular}{|c|c|c|c|c|c|c|c|c|}
\hline & & 28.3991 & & & & & & \\
\hline 13 & 12.5759 & $\begin{array}{l}- \\
15.9868\end{array}$ & 1.0000 & 0.9958 & 1.0000 & 0.9917 & 0.9937 & 2 \\
\hline 14 & 12.2824 & $\begin{array}{l}- \\
18.8897\end{array}$ & 0.9472 & 0.8917 & 0.9044 & 0.8219 & 0.8417 & 4 \\
\hline 15 & 8.4076 & $\begin{array}{l}- \\
26.4856\end{array}$ & 0.0531 & 0.3792 & 0.3456 & 0.4461 & 0.4220 & 13 \\
\hline $\begin{array}{l}\text { o. } \\
\text { exp. }\end{array}$ & $\begin{array}{c}\mathrm{S} / \mathrm{N} \\
\text { ratio for } \\
\mathrm{CoF}\end{array}$ & $\begin{array}{c}\mathrm{S} / \mathrm{N} \\
\text { ratio for } \\
\text { wear } \\
\text { loss }\end{array}$ & $\begin{array}{c}\text { ORM. } \\
\text { CoF }\end{array}$ & $\begin{array}{l}\text { ORM. } \\
\text { Wear } \\
\text { loss }\end{array}$ & $\begin{array}{c}\text { rey } \\
\text { coefficient } \\
\mathrm{CoF}\end{array}$ & $\begin{array}{c}\text { rey } \\
\text { coefficient } \\
\text { Wear loss }\end{array}$ & RG & ANK \\
\hline 6 & .2815 & 29.6001 & .0168 & .0000 & $.3371^{0}$ & $.3333^{0}$ & .3342 & 6 \\
\hline
\end{tabular}

The variation of grey relation grade results is shown in Figure 1. Maximum tribological characteristics for all experimental investigations can be found for case when grey relation grade is the highest. In this investigation, it is seen that for experiments number 4 and 13 are obtained maximum tribological characteristics. The best optimal characteristic was found based on the ranking in Table 5 .

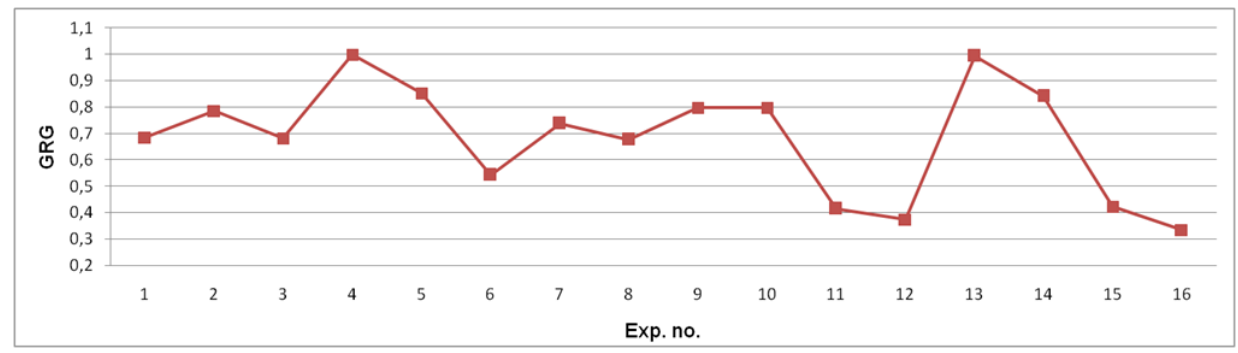

Figure 1 Grey relation grade for the maximum tribological characteristics

The GRC, GRG and the rank of each experiment were found from Eqs. (1) - (6), and the results are shown in Table 5. These results are in accordance with Table 6, which is the response table for the grey relational grade. The optimum level of each experiment parameter is bolded value given in Table 6 and shown in Figure 2.

Table 6 Response table for grey relational grade

\begin{tabular}{|l|l|l|l|}
\hline \multirow{2}{*}{ Level } & \multicolumn{2}{|l|}{ Parameters } \\
\cline { 2 - 4 } & A & B & C \\
\hline 1 & $\mathbf{- 2 . 1 8 7}$ & $\mathbf{- 1 . 6 7 8}$ & -6.442 \\
\hline 2 & -3.184 & -2.721 & -4.888 \\
\hline
\end{tabular}




\begin{tabular}{|l|l|l|l|}
\hline 3 & -5.031 & -5.276 & -2.545 \\
\hline 4 & -4.641 & -5.369 & $\mathbf{- 1 . 1 6 8}$ \\
\hline Delta (max-min) & 2.844 & 3.691 & 5.274 \\
\hline Rank & 3 & 2 & 1 \\
\hline
\end{tabular}

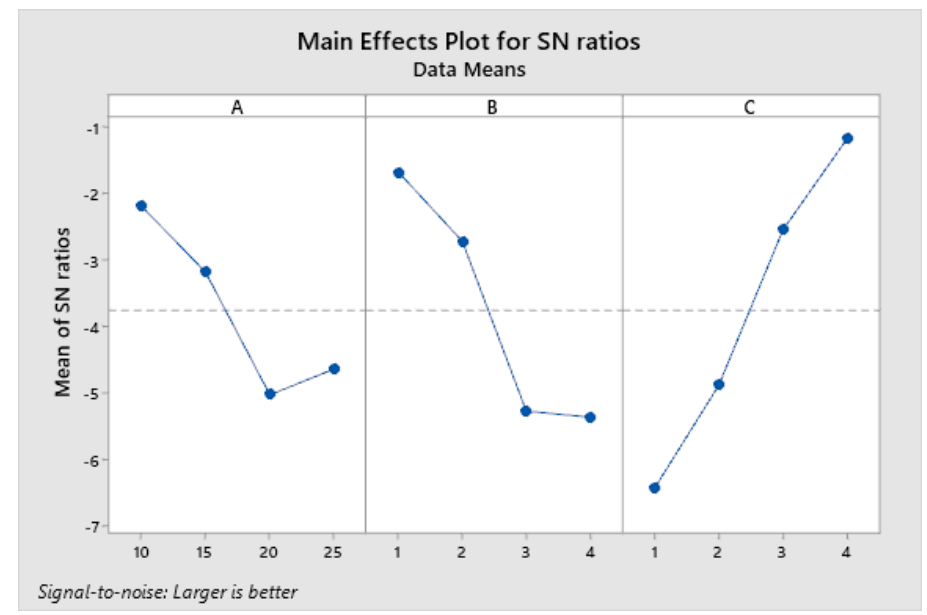

Figure 2 Effect of each parameter on multiple responses

According to the GRG given in Table 5 optimum value was obtained at A1B4C4, with the rank 1. However from Table 6 main optimum levels of the parameters were obtained at A1B1C4 according to the mean GRG. This happens because design of experiment by which there are not needed all combinations of parameters, but with great reliability optimum parameter levels can be achieved with little experimental data by using Taguchi based GRA which will be proven with confirmation test. To investigate the significance of load, reinforcement $\mathrm{Gr}$ and reinforcement $\mathrm{Al}_{2} \mathrm{O}_{3}$ on the tribological characteristics, the analysis of variance (ANOVA) was conducted for the average GRG responses at the $95 \%$ confidence level. The results of GRG are evaluated within the ANOVA method and contribution ratios of each parameter are presented in Table 7. Statistical effect of all observed parameters was obtained. Last column of Table 7 shows the contribution percentage (\%) of each parameter on the GRG. ANOVA analysis shows that the highest effect has reinforcement content $\mathrm{Al}_{2} \mathrm{O}_{3}$, and then effect of reinforcement content $\mathrm{Gr}$ on multi response optimization of tribological characteristics with $48.61 \%$ and $30.07 \%$, respectively. The least effect with $15.17 \%$ has load, while error has effect of $6.16 \%$. On the Figure 3 are ilustrated the response contour plots for illustrating effects of load, reinforcement content $\mathrm{Gr}$ and $\mathrm{Al}_{2} \mathrm{O}_{3}$ on GRG.

Table 7 Analysis of Variance for Grey relational grade

\begin{tabular}{|c|c|c|c|c|c|c|c|}
\hline $\begin{array}{c}\text { Parameter } \\
\text { S }\end{array}$ & DOF & Seq SS & Adj SS & AdjMS & F & P & $\begin{array}{c}\text { Contributi } \\
\text { on }(\%)\end{array}$ \\
\hline A & 3 & 20.793 & 20.793 & 6.931 & 4.93 & 0.047 & 15.17 \\
\hline B & 3 & 41.217 & 41.217 & 13.739 & 9.77 & 0.010 & 30.07 \\
\hline
\end{tabular}




\begin{tabular}{|c|c|c|c|c|c|c|c|}
\hline C & 3 & 66.640 & 66.640 & 22.213 & 15.79 & 0.003 & 48.61 \\
\hline $\begin{array}{c}\text { ResidualE } \\
\text { rror }\end{array}$ & 6 & 8.441 & 8.441 & 1.407 & & & 6.16 \\
\hline Total & 15 & 137.091 & & & & & 100.00 \\
\hline
\end{tabular}
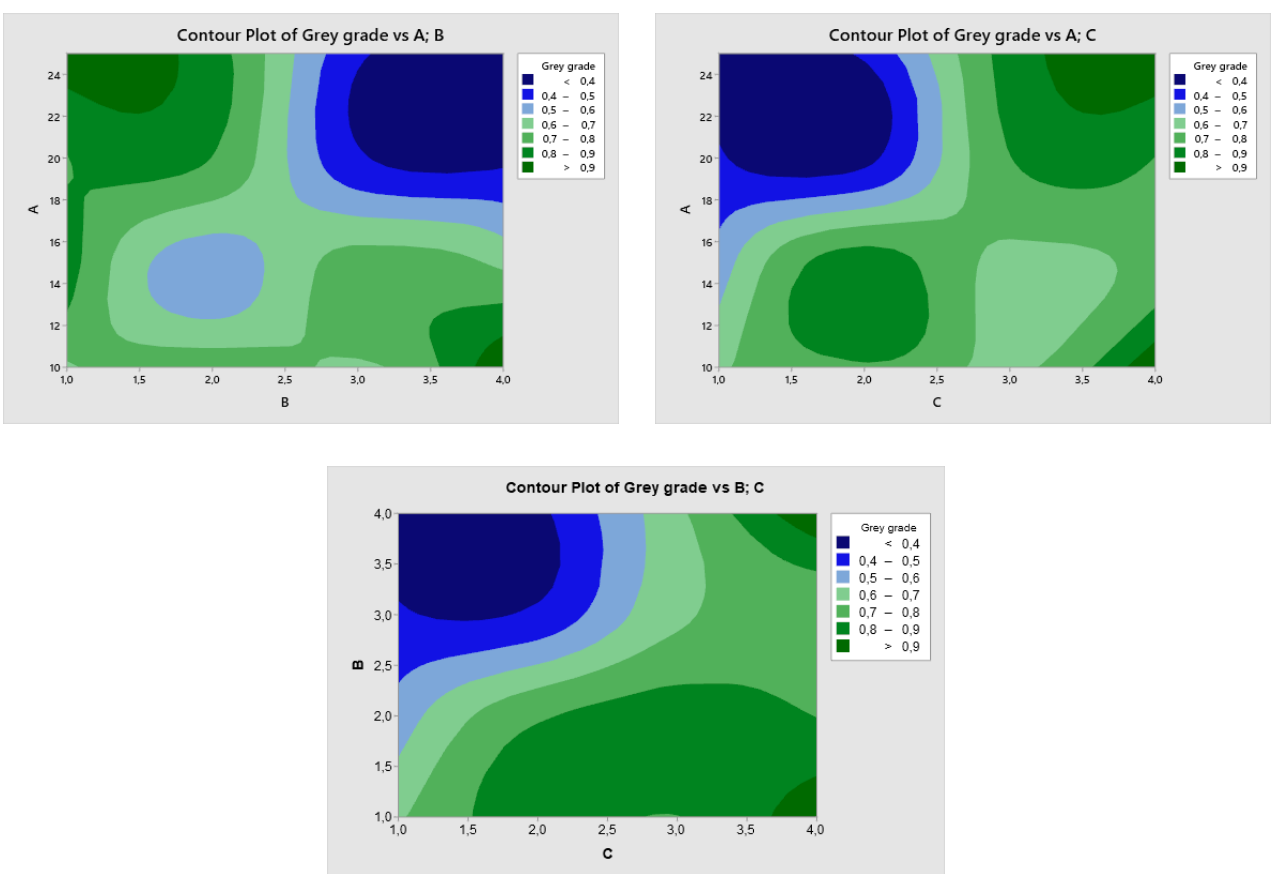

Figure 3 Effect of each parameter interactions on GRG: a) Effect of load and content of $G r, b)$ Effect of load and content of Al2O3, c) Effect of content of Gr and content of Al2O3

The effect of parameters on GRG can be determined based on shades of two colors (blue and green) i.e. deep green shows the highest effect of parameter interaction on GRG while deep blue shows the least effect of parameter interaction on GRG. Interection between load and content of Gr (Figure 3a) shows that GRG is the highest for load of $10 \mathrm{~N}$ and content of 4 vol.\% Gr. The same applies for interaction between load and content of $\mathrm{Al}_{2} \mathrm{O}_{3}$ (Figure $3 \mathrm{~b}$ ) the highest GRG is for load of $10 \mathrm{~N}$ and content of 4 vol. $\% \mathrm{Al}_{2} \mathrm{O}_{3}$. As for effect of the interaction between reinforcement contents of $\mathrm{Gr}$ and $\mathrm{Al}_{2} \mathrm{O}_{3}$ (Figure 4) highest GRG is for 1 and 4 vol.\% $\mathrm{Gr}$ and 4 vol. $\% \mathrm{Al}_{2} \mathrm{O}_{3}$, which is according to optimal combinations obtained with Taguchi Grey analysis.

\subsection{Confirmation experiments}

The last and very important step of multi response optimization is confirmation experiment for optimal parameters level. The purpose of confirmation test is to validate conclusions from analysis stage. In Taguchi Grey analysis confirmation test is done if optimal combinations of parameters are different between GRA and $\mathrm{S} / \mathrm{N}$. Optimal parameter combination with GRG and $\mathrm{S} / \mathrm{N}$ was $\mathrm{A} 1 \mathrm{~B} 4 \mathrm{C} 4$ and $\mathrm{A} 1 \mathrm{~B} 1 \mathrm{C} 4$ respectively. Because combination A1B1C4 was not done experimentally in orthogonal array, confirmation 
experiment was done for this combination. Results of confirmation test for optimum parameters are given in Table 8 .

Table 8 Analysis of Variance for Grey relational grade

\begin{tabular}{|c|c|c|c|c|}
\hline $\begin{array}{c}\text { Optimal } \\
\text { combination }\end{array}$ & \multicolumn{2}{|c|}{ Experiment } & \multicolumn{2}{c|}{ Prediction } \\
\hline A1B1C4 & $\begin{array}{c}\text { Experimental } \\
\text { results }\end{array}$ & $\begin{array}{c}\text { GRG for } \\
\text { experimental } \\
\text { value }\end{array}$ & Results & GRG \\
\hline CoF & 0.21592 & 1 & 0.216 & \multirow{2}{*}{0.9986} \\
\hline Wear loss & 4.6 & 4.61 & \\
\hline
\end{tabular}

After the experiment $\mathrm{CoF}$ and wear loss were 0.21592 and 4.6 respectively. Then GRG was calculated as 1 which proves that this is the optimal combination of parameters. Prediction of GRG with the use of Taguchi was done as well and value of GRG was 0.9986 which is very close to the GRG of experimental value. Based on prediction of GRG values for CoF and wear loss were calculated and they are very close to experimental ones and they are presented in Table 8 .

\section{CONCLUSIONS}

Based on the results in this study it can be concluded that Taguchi based Grey relational analysis is very useful tool for multi response optimization of tribological behaviour of zinc based nanocomposites with different reinforcement content. Observed responses of this investigation were $\mathrm{CoF}$ and wear loss. Because there was more than one response, in order to optimize these nanocomposites, the multi response methods are applied. In this paper GRA is used for multi response optimization of parameters load, content reinforcements $\mathrm{Al}_{2} \mathrm{O}_{3}$ and $\mathrm{Gr}$ on tribological behaviour nanocomposite. The highest GRG was obtained for combination A1B4C4 more precisely $10 \mathrm{~N}, 4$ vol. $\% \mathrm{Gr}$ and 4 vol. $\% \mathrm{Al}_{2} \mathrm{O}_{3}$. From analysis of $\mathrm{S} / \mathrm{N}$ ratio of GRG different combination was obtained noted as A1B1C4 i.e. 10N, 1 vol.\% $\mathrm{Gr}$ and 4 vol. $\% \mathrm{Al}_{2} \mathrm{O}_{3}$. Confirmation experiment validated the improvement of $\mathrm{CoF}$ and wear loss for combination obtained by $\mathrm{S} / \mathrm{N}$. From the ANOVA analysis of GRG it is noted that reinforcement content of $\mathrm{Al}_{2} \mathrm{O}_{3}$ is the most significant parameter affecting the tribological behaviour of nanocomposites with $48.61 \%$, following reinforcement content of $\mathrm{Gr}$ and load with $30.07 \%$ and $15.17 \%$, respectively. Future research can be focused on investigation of influence of the wider range of reinforcement content on the composites' properties. It is also possible to do multi optimization by observing tribological and mechanical properties in order to obtain materials with the best characteristics.

\section{ACKNOWLEDGMENTS}

The paper was written during research funded by the Ministry of Education, Science and Technological Development. Besides, the authors of the present study thank to TÜBİTAK (Scientific and Technological Research Council of Turkey) for their financial support of the projects with the Project Number 213M276.

\section{REFERENCES}

[1] Veličković, S., Stojanović, B., Ivanović, L., Miladinović, S., Milojević, S.: "Application of nanocomposites in the automotive industry", Mobility and Vehicle Mechanics, 2019, Vol. 45, No. 3, pp. 51-64. Doi: 10.24874/mvm.2019.45.03.05. 
[2] Vučetić, F., Veličković, S., Milivojević, A., Vencl, A.: "A review on tribological properties of microcomposites with ZA-27 alloy matrix", 15th International Conference on Tribology - Serbiatrib‘17, Faculty of Engineering University of Kragujevac, Kragujevac, Serbia, 2017, 17 - 19 May, pp. 169-176.

[3] Babic, M., Stojanovic, B., Dzunic, D., Pantic, M.: "Micro/nanoscale structural, mechanical and tribological characterization of ZA-27/SiC nanocomposites", Journal of Composite Materials, 2020, Vol. 54, No. 16, pp. 2113-2129. Doi: 10.1177/0021998319891766.

[4] Güler, O., Cuvalci, H., Canakci, A., Celebi, M.: "The effect of nano graphite particle content on the wear behaviour of ZA27 based hybrid composites", Advanced Composites Letters, 2017, Vol. 26, No. 2, pp. 30-36. Doi: $\underline{10.1177 / 096369351702600201 .}$.

[5] Pul, M.: "Effect of sintering temperature on pore ratio and mechanical properties of composite structure in nano graphene reinforced ZA27 based composites", International Journal of Minerals, Metallurgy and Materials, 2020, Vol. 27, pp. 1-12. Doi: 10.1007/s12613-019-1926-2.

[6] Kumar, N. S.: "Mechanical and wear behavior of ZA-27/Sic/Gr hybrid metal matrix composites", Materials Today: Proceedings, 2018, Vol. 5, No. 9, pp. 19969-19975. Doi: $10.1016 /$ j.matpr.2018.06.363.

[7] Almomani, M. A., Hayajneh, M. T., Alelaumi, S. M.: "Applying Taguchi method to study the wear behaviour of ZA-27 alloy-based composites reinforced with SiC nanoparticles", International Journal of Cast Metals Research, 2019, Vol. 32, No. 4, pp. 229-241. Doi: 10.1080/13640461.2019.1643061.

[8] Shivakumar, N., Vasu, V., Narasaiah, N.: "Processing and dry sliding wear behavior of Al2O3 nanoparticles reinforced ZA-27 composites", Materials Today: Proceedings, 2017, Vol. 4 No. 2, pp. 4006-4012. Doi: 10.1016/j.matpr.2017.02.302.

[9] Bobić, B., Vencl, A., Ružić, J., Bobić, I., Damnjanović, Z.: "Microstructural and basic mechanical characteristics of ZA27 alloy-based nanocomposites synthesized by mechanical milling and compocasting", Journal of Composite Materials, 2019, Vol. 53, No. 15, pp. 2033-2046. Doi: 10.1177/0021998318817876.

[10] Karimzadeh, F., Enayati, M. H., Tavoosi, M.: "Synthesis and characterization of $\mathrm{Zn} / \mathrm{Al} 2 \mathrm{O} 3$ nanocomposite by mechanical alloying", Materials Science and Engineering: 2008, A, Vol. 486, No. 1-2, pp. 45-48. Doi: 10.1016/j.msea.2007.08.059.

[11] Güler, O., Çuvalcı, H., Gökdağ, M., Çanakçi, A., Çelebi, M.: "Tribological behavior of ZA27/A12O3/graphite hybrid nanocomposites", Particulate Science and Technology, 2018, Vol. 36, No. 7, pp. 899-907. Doi: 10.1080/02726351.2017.1326994.

[12] Veličković, S., Stojanović, B., Babić, M., Bobić, I.: “Optimization of tribological properties of aluminum hybrid composites using Taguchi design", Journal of composite materials, 2017, Vol. 51, No. 17, pp. 2505-251. Doi: 10.1177/0021998316672294.

[13] Dey, A., Debnath, S., Pandey, K. M.: “Optimization of electrical discharge machining process parameters for A16061/cenosphere composite using grey-based hybrid approach", Transactions of Nonferrous Metals Society of China, 2017, Vol. 27, No. 5, pp. 998-1010. Doi: 10.1016/S1003-6326(17)60117-1. 